This item was submitted to Loughborough's Research Repository by the author.

Items in Figshare are protected by copyright, with all rights reserved, unless otherwise indicated.

\title{
When do customers get what they expect? Understanding the ambivalent effects of customers' service expectations on satisfaction
}

PLEASE CITE THE PUBLISHED VERSION

https://doi.org/10.1177/1094670516662350

\section{PUBLISHER}

(c) The Authors. Published by Sage

\section{VERSION}

AM (Accepted Manuscript)

\section{PUBLISHER STATEMENT}

This work is made available according to the conditions of the Creative Commons Attribution-NonCommercialNoDerivatives 4.0 International (CC BY-NC-ND 4.0) licence. Full details of this licence are available at: https://creativecommons.org/licenses/by-nc-nd/4.0/

\section{LICENCE}

CC BY-NC-ND 4.0

\section{REPOSITORY RECORD}

Habel, Johannes, Sascha Alavi, Christian Schmitz, Janina-Vanessa Schneider, and Jan Wieseke. 2019. "When Do Customers Get What They Expect? Understanding the Ambivalent Effects of Customers' Service Expectations on Satisfaction". figshare. https://hdl.handle.net/2134/33437. 


\title{
When Do Customers Get What They Expect? \\ Understanding the Ambivalent Effects of Customers' Service Expectations on Satisfaction
}

\begin{abstract}
Extant research established that customers' expectations play an ambivalent role in the satisfaction formation process: while higher expectations are more difficult to meet and thus cause dissatisfaction, they simultaneously increase satisfaction via customers’ perceived performance owing to a placebo effect. However, to date, knowledge is scarce on the question under which conditions either the positive or negative effect of expectations on satisfaction prevails. Building on information processing theory, the authors hypothesize that an essential contingency of the indirect, placebo-based effect is the degree to which customers are able and motivated to process a service experience. Three studies with a total of over 4,000 customers in different service contexts provide strong evidence for this hypothesis. Thus, managers are well advised to provide a realistic or even understated prospect if the service context favors customers' ability or motivation to evaluate. Conversely, if customers are neither able nor motivated to evaluate the service, increasing customer expectations represents a viable strategy to enhance satisfaction. Relatedly, if customers hold low service expectations, managers should foster customers' ability and motivation to evaluate the service. In contrast, if service expectations are high, managers may benefit from reducing the likelihood that customers overly focus on the service performance.
\end{abstract}

Keywords: service expectations; customer satisfaction; information processing; ability to evaluate; motivation to evaluate 
Imagine that you are the chief marketing officer of an airline. When planning the communication towards customers who have booked a flight, would you attempt to tone customers' expectations down to give them a less positive outlook or boost customers' expectations to provide them with a rose-colored prospect of the flight? You might find good reasons for both options: Decreasing expectations might allow your airline to perform even better than customers expected, hereby fostering customer satisfaction. However, increasing service expectations may bias customers to perceive the service experience in a more favorable light.

The question how to manage customers’ service expectations in a satisfaction optimizing way is of critical importance not only for airlines, but for service firms in general, and practitioners have answered this question differently. For instance, delivery service providers such as Amazon understate their delivery speed to pleasantly surprise their customers (Ho and Zheng 2004; Munoz 2014). Relatedly, restaurants exaggerate the amount of time to get a table (Kopalle and Lehmann 2006) and management consultancies strive to surprise customers in an “under-promise over-deliver fashion” (Ojasalo 2001). In contrast, for instance, AT\&T Universal Card Services deliberately increases its customers’ expectations (Kurtz and Clow 1992). Similarly, physicians raise customers' expectations by displaying their diplomas on the walls and public speakers are talked up in their introductions (Goldstein, Martin, and Cialdini 2008).

Practitioners’ conflicting approaches how to manage customer expectations are reflected in marketing research. Strikingly, to date, academia does not provide clear-cut recommendations for practitioners on how to manage expectations: Recommendations range from increasing expectations (e.g., Boulding, Kalra, and Staelin 1999) to keeping expectations at the level of the actual performance (e.g., Parasuraman, Berry, and Zeithaml 1994) to decreasing expectations (e.g., Davidow and Uttal 1989). 
The reason for these conflicting recommendations is that customer expectations exert an ambivalent effect on customer satisfaction — that is, expectations are simultaneously positively as well as negatively related to satisfaction. To elaborate, regarding the negative effect, as higher expectations are more difficult to meet, increasing customers' expectations tends to evoke disconfirmation and thus negatively influence satisfaction (e.g., James 2007; Poister and Thomas 2011). Regarding the positive effect, customer expectations increase satisfaction by increasing customers’ perceived product or service performance (e.g., Anderson and Sullivan 1993; Gupta and Stewart 1996; Oliver, Balakrishnan, and Barry 1994), reflecting a placebo effect (Shiv, Carmon, and Ariely 2005). Perceived performance in turn positively influences satisfaction (e.g., Anderson and Sullivan 1993; Gupta and Stewart 1996; Patterson, Johnson, and Spreng 1997).

Owing to its counter-intuitive nature, the before-mentioned placebo effect has intrigued marketing researchers for some time. To understand when this placebo effect occurs, researchers have begun to examine the contingencies which determine whether customers' expectations indeed increase performance perceptions (e.g., Anderson 1973; Irmak, Block, and Fitzsimons 2005; Voss, Parasuraman, and Grewal 1998). However, despite initial evidence of contingencies, further research is needed to explore the contingent role of customer expectations in service encounters for two reasons. First, existing articles to date analyze moderating factors of the expectation-perceived performance linkage in a piecemeal manner without providing a coherent theoretical account of moderating influences. Second, prior research has not comprehensively assessed the effects of expectations on customer satisfaction, accounting for the ambivalent nature of expectations. More specifically, to date it is unclear under which circumstances the positive impact of expectations on satisfaction (via the placebo effect) outweighs the negative impact (via expectation disconfirmation). Answering the question when expectations increase or 
decrease satisfaction is instrumental to derive recommendations on how to manage customers' expectations optimally.

This is the starting point for our paper: It is our key goal to expand the literature on contingencies of the placebo effect in service settings. Specifically, we aim to examine the impact of contingency factors on the overall effect of service expectations on customer service satisfaction formation. As a basis for our conceptualization, we draw on information processing theory (e.g., Chaiken 1980; Sujan 1985; Sujan, Bettman, and Sujan 1986). We argue that customers' type of information processing constitutes a key contingency of the placebo effect: It is more pronounced for customers who process information on the service experience heuristically and less pronounced for customers who process information on the service experience systematically. Two key determinants of systematic information processing are individuals’ ability to evaluate and motivation to evaluate (Petty and Cacioppo 1986). Based on this logic, in this paper we argue that ability and motivation to evaluate weaken the placebo effect of service expectations on perceived service performance.

To test our predictions, we conducted three studies in different service contexts. In Study 1 we tested the moderating influence of ability and motivation to evaluate on the expectationperceived performance relationship using a longitudinal naturalistic study with 327 customers in a movie theater context. Results indicate that if customers score high in ability or motivation to evaluate the effect of service expectations on service satisfaction via perceived service performance becomes less pronounced. In Study 2, an experimental simulation with 129 participants, we verified the robustness of these findings in a restaurant setting. Eventually, in Study 3 we used longitudinal survey and matched objective data from 3,704 customers of an 
airline to verify the external validity of our findings. Results show that our previous findings translate to objective firm financial outcomes.

Our paper holds important implications for researchers and practitioners. For researchers, our findings help to clarify the ambivalent role of service expectations in the process of service satisfaction formation. In particular, our results provide insights under which conditions the positive effect of expectations on customer satisfaction via perceived service performance presides over the direct negative effect of expectations on satisfaction. Hereby, our study contributes to research on customers' evaluation of services and lays the groundwork for further research, e.g., in the fields of service failure and service recovery. Our findings also provide direct, actionable implications for service managers and employees. If the service context favors customers' systematic information processing by promoting ability or motivation to evaluate, service providers should refrain from boosting customer expectation and provide a realistic or even understated prospect. If customers are neither able nor motivated to evaluate the service and are thus likely to process information heuristically, increasing customer expectations represents a viable strategy to enhance satisfaction.

\section{Conceptual Framework}

Figure 1 displays the conceptual framework of the paper and the Appendix depicts definitions of all constructs. In what follows, we describe the purpose of the studies and the construct relationships. In Study 1, we tested our core prediction that service expectations exert ambivalent effects on service satisfaction through (a) a direct negative path and (b) an indirect positive path via perceived service performance. We conceive service expectations as 'will' expectations, defined as a customer's prediction on what an offering is going to deliver (Golder, Mitra, and Moorman 2012; Boulding et al. 1993; Zeithaml, Berry, and Parasuraman 1993). Thus, in 
comparison to other types of service expectations—e.g., 'should' expectations or 'ideal' expectations-'will' expectations capture the anticipation of the future service performance. Our decision to conceptualize service expectations as 'will' expectations is firmly in line with prior marketing research on placebo effects (e.g., Irmak, Block, and Fitzsimons 2005; Lee, Frederick, and Ariely 2006). In accordance with extant research, we anticipate that service expectations increase perceived service performance (Oliver and Burke 1999; Oliver, Balakrishnan, and Barry 1994). Furthermore, we argue that both service expectations and perceived service performance affect service satisfaction which transfers to loyalty to the service provider. Beyond these causally linked constructs, based on information processing theory (e.g., Sujan, Bettman, and Sujan 1986), we expect that customers' ability to evaluate and motivation to evaluate moderate the effect of service expectations on perceived service performance (Petty and Cacioppo 1986). In Study 2, we replicated Study 1 in a different service context and experimentally manipulated customers' service expectations and customers' ability to evaluate. Specifically, we examine how the experimentally manipulated ability to evaluate moderates the effect of experimentally induced service expectations on perceived performance.

Eventually, in Study 3, we aimed to verify the external and predictive validity of our prior findings by examining the interactive effect of service expectations and motivation to evaluate on sales growth. As Study 3 serves as a validation for our prior findings, we refrain from deriving formal hypotheses on the relationships tested in this study. 


\section{Research Hypotheses}

\section{The Linkage of Service Expectations, Perceived Service Performance, and Service Satisfaction}

Service expectations $\rightarrow$ perceived service performance. We propose that service expectations positively affect perceived service performance. We base this proposition on literature examining the placebo effect in marketing. Studies in this stream of literature have found that customers tend to evaluate service performance in line with their prior expectations (e.g., Anderson and Sullivan 1993; Gupta and Stewart 1996; Oliver, Balakrishnan, and Barry 1994), reflecting a placebo effect. Such placebo effects occur due to individuals’ common tendency to seek confirmation of their expectations (Nickerson 1998). To illustrate, if a customer holds positive expectations of a restaurant, during the restaurant visit she might focus her attention on positive service elements allowing her to confirm her prior expectations. Thus, we hypothesize:

$H_{1}$ : Service expectations positively affect perceived service performance. That is, high (low) levels of service expectations induce high (low) service performance perceptions.

Service expectations $\rightarrow$ service satisfaction. We propose that service expectations have a negative direct effect on service satisfaction. We derive this proposition from literature on confirmation-disconfirmation. According to this stream of literature, customer satisfaction results from customers' comparison of perceived performance with their prior expectations (e.g., Oliver 1980). Specifically, if customers perceive performance as lower (higher) than their expectations, customers experience negative (positive) disconfirmation, leading to dissatisfaction (satisfaction). Extending our before-mentioned restaurant example, the higher the customer's expectations of the restaurant's service, the less likely it is that the customer's expectations are met or exceeded by the restaurant's performance. Thus:

$\mathrm{H}_{2}$ : Service expectations negatively affect service satisfaction. That is, high (low) levels of service expectations induce low (high) service satisfaction. 
Perceived service performance $\rightarrow$ service satisfaction. We propose that perceived service performance positively affects service satisfaction. Again, this proposition can be directly derived from literature on confirmation-disconfirmation (e.g., Anderson 1973; Oliver 1980). In particular, the higher customers' perceived service performance, the more likely it is that this perceived service performance fulfills customers' service-related needs, which represents the key prerequisite for customer satisfaction to occur. Regarding the restaurant example, if the restaurant delivers outstanding service, chances are high that the customer's prior expectations are met by her perception of this service. Hence, we put forth:

$\mathrm{H}_{3}$ : Perceived service performance positively affects service satisfaction. That is, high (low) levels of perceived service performance induce high (low) service satisfaction.

\section{Contingencies of the Effect of Service Expectations on Service Satisfaction}

On the basis of information processing theory (e.g., Sujan, Bettman, and Sujan 1986) we hypothesize that customers' ability and motivation to evaluate determine the strength of the effect of service expectations on perceived service performance. Therefore, in the following we first describe information processing theory and then apply it to our research question.

Information processing theory. According to information processing theory, individuals may process information in two fundamentally distinct ways (Chaiken 1980). First, individuals may utilize systematic processing where incoming information from stimuli are processed in a piecemeal manner (Sujan 1985; Sujan, Bettman, and Sujan 1986). Because of this detailed processing, systematic processing is an effortful task that requires a lot of processing capacity (Yoon 1997). Processing capacity is defined as the "amount of working memory allocated to an attended stimulus” (MacInnis and Jaworski 1989, p. 5). 
Second, individuals may utilize heuristic processing. Hereby, information processing is based on preexisting knowledge structures which serve as simplifying mechanisms to process incoming information (Sujan, Bettman, and Sujan 1986). Therefore, heuristic processing serves as an aid to facilitate information processing (Herr 1989) and makes it less effortful (Yoon 1997).

The role of information processing for customers' service perceptions. Based on information processing theory we argue that the relationship between service expectations and perceived service performance (see $\mathrm{H}_{1}$ ) depends on how customers process information when evaluating the service. In particular, if customers process information heuristically, they resort to a mental short-cut and base their evaluation on preexisting knowledge structures. Customers’ service expectations represent such preexisting knowledge structures. As a result, customers are likely to process particularly those elements of the service performance which confirm prior expectations, blocking out conflicting perceptions-a phenomenon also known as confirmation bias (Nickerson 1998).

In contrast, if customers process information systematically, they concentrate on the actual service experience in detail. As a result, they are more likely to take into account information which contradicts their previously held expectations. Hence, if customers process the service experience systematically, they should be less likely to base their evaluation of the service performance on their expectations.

Two key predictors of individuals’ type of information processing are individuals’ ability to evaluate and motivation to evaluate (Petty and Caciopoppo 1986). Therefore, in the following, we propose that customers' ability and motivation to evaluate determine to what extent customers factor in their service expectations when evaluating service performance. Specifically, 
we propose that the indirect effect of service expectations on service satisfaction via perceived service performance is weakened the higher customers’ ability and motivation to evaluate, because these customer process the service experience more systematically, or, respectively, less heuristically.

The role of ability to evaluate. Customers endowed with high levels of ability to evaluate are able to invest considerable mental resources to scrutinize and monitor the service performance (Jain and Maheswaran 2000). As a result, customers high in ability to evaluate are particularly likely to process the service systematically (Petty and Caciopoppo 1986). Therefore, we expect these customers to comprehensively utilize available information on the service to form their assessment of the service performance rather than relying on their prior expectations.

Conversely, customers with low ability to evaluate have fewer cognitive resources to scrutinize the service performance and are therefore more likely to process their experience less systematically, or, respectively, more heuristically (Petty and Caciopoppo 1986). As outlined above, this might lead customers to concentrate on information which confirms their prior expectations (Nickerson 1998), increasing the influence of customers' expectations on perceived serviced performance.

Motivation to evaluate. Relatedly, we propose that the effect of service expectations on perceived service performance is less pronounced if customers have a high motivation to evaluate incoming information, weakening the indirect effect of service expectations on service satisfaction. Individuals with a high motivation to evaluate are likely to evaluate their surrounding in an all-embracing manner (Jarvis and Petty 1996). In other words, these individuals feel a comparatively strong need to evaluate external stimuli they encounter in order to achieve cognitive mastery of their environment (Bizer et al. 2004). Therefore, when 
consuming a service these individuals should be more likely to process their experience systematically rather than heuristically. As argued previously, they should therefore be less likely to bias their perceptions toward their preexisting expectations.

In contrast, individuals with a low motivation to evaluate are likely to process information less systematically, or, respectively, more heuristically (Petty and Caciopoppo 1986). Thus, information processing theory suggests that these individuals process particularly those elements of a service experience which confirms their prior service expectations (Nickerson 1998). As a result, these individuals should therefore be more likely to bias their perceptions toward their expectations. Thus, we hypothesize:

$\mathrm{H}_{4}$ : The higher the customer's ability to evaluate, the weaker is the indirect effect of service expectations on service satisfaction via perceived service performance.

$H_{5}$ : The higher the customer's motivation to evaluate, the weaker is the indirect effect of service expectations on service satisfaction via perceived service performance.

\section{Study 1: How Do Ability and Motivation to Evaluate Affect the Expectation-Satisfaction}

\section{Linkage?}

\section{Data Collection and Sample}

We collected the data for Study 1 in a movie theater, which is a frequently chosen context in service research (e.g., Hennig-Thurau, Marchand, and Hiller 2012). We generated a longitudinal data set which comprises two measurement points, that is, one pre-measurement directly before and one post-measurement after the movie. Therefore, our research team approached customers before the start of their movie and asked them answer a short questionnaire. After the movie, participants were invited to answer an online questionnaire to measure perceived service performance and service satisfaction. The final sample consisted of 327 customers providing 
responses prior to and after the movie experience (for a response rate of 57\%; 53\% women; mean age of 31).

\section{Measurement Sources, Validity, and Reliability}

Main variables. We surveyed service expectations in the questionnaire before the movie. The online questionnaire contained the remaining constructs, i.e., customer loyalty to the service provider, service satisfaction, perceived service performance, ability to evaluate, and motivation to evaluate. We used established scales for all measures. Ability to evaluate comprises the items “I notice when product performance does not match the quality I expect from the product” and "I realize when product performance does not match my prior expectations” (Petty and Caciopoppo 1986; Kopalle and Lehmann 2001). Motivation to evaluate was measured using three items: "I want to know exactly what is good and bad about everything," "I like to decide that new things are really good or really bad,” and "I pay a lot of attention to whether things are good or bad,” (Jarvis and Peatty 1996). Thus, we measured customers' general predispositions rather than situationally driven ability and motivation to evaluate.

Controls. We controlled for customers’ demographics by including the variables gender and age. Moreover, as customers’ performance perceptions and satisfaction may depend on the customer-company relationship, we controlled for pre-consumption customer loyalty to the movie theater. Lastly, customers' evaluation of a movie may be substantially influenced by their current affective state (Batra and Stayman 1990; Baumgartner, Sujan, and Bettman 1992; Forgas and George 2001). Therefore, we controlled for customers’ positive mood as well as the interaction of customers’ positive mood and service expectations. To avoid that our measures of pre-consumption customer loyalty and positive mood were influenced by the focal movie, we collected these variables in the questionnaire distributed before the movie. 
Please refer to the Appendix for a complete list of our measures including psychometric properties and to Table 1 for descriptive statistics and correlations. All scales exceed common thresholds in terms of reliability as well as convergent and discriminant validity (Bagozzi and Yi 1988; Fornell and Larcker 1981). Lastly, we ensured that common method variance is not an issue in our data. Therefore, we conducted the post-hoc marker variable correction of common method variance proposed by Lindell and Whitney (2001) and tested for common method variance by including a latent method factor in our measurement model (Podsakoff et al. 2003). Both tests suggest that our data is not unduly influenced by common method variance. Prior to the estimation, we mean-centered all interacting variables (Cohen et al. 2003).

Insert Table 1 about here

\section{Model Estimation and Results}

As our data set includes customers nested in 24 different movies, we assessed whether a multilevel approach is required by inspecting the intraclass correlation coefficients (ICC) of perceived service performance and service satisfaction. A multilevel approach is warranted when ICCs exceed .15 (Hox 2010), which was the case in our study $\left(\right.$ ICC $_{\text {perceived service performance }}=.163$; $\mathrm{ICC}_{\text {service satisfaction }}=.175$ ). Therefore, we specified a multilevel path model (between level: movies, within level: customers) and estimated this model using Mplus 7 (Muthén and Muthén 2012). Model 1 in Table 2 depicts the estimated path coefficients. Furthermore, Table 3 depicts a floodlight analysis (Spiller et al. 2013), presenting the simple slope of service expectations on perceived service performance as well as the indirect and total effects of service expectations on service satisfaction for different levels of the tested moderators.

Insert Table 2 about here 
First, we note that the results confirm $\mathrm{H}_{1}, \mathrm{H}_{2}$, and $\mathrm{H}_{3}$. That is, service expectations have a positive effect on perceived service performance (supporting $\mathrm{H}_{1}$ ) and a negative effect on service satisfaction (supporting $\mathrm{H}_{2}$ ). Furthermore, perceived service performance has a positive effect on service satisfaction (supporting $\mathrm{H}_{3}$ ). Please refer to Table 2 for details on the path coefficients.

Turning to the moderation hypotheses, in $\mathrm{H}_{4}$ we argued that ability to evaluate negatively moderates the indirect effect of service expectations on service satisfaction via perceived service performance. Again, Table 2 shows that ability to evaluate moderates the direct effect of service expectations on perceived service performance $(\beta=-.158, \mathrm{p}<.01)$. Furthermore, as displayed in Table 3, the indirect effect of service expectations on service satisfaction depends on ability to evaluate, confirming $\mathrm{H}_{4}$.

Similarly, in $\mathrm{H}_{5}$ we suggested that motivation to evaluate negatively moderates the indirect effect of service expectations on service satisfaction via perceived service performance. This hypothesis is supported: Table 2 shows that the interactive effect of service expectations and motivation to evaluate on perceived service performance is negative and significant $(\beta=$ $.163, \mathrm{p}<.01$ ) and Table 3 confirms that the indirect effect of service expectations on satisfaction is significantly moderated by motivation to evaluate. Please refer to Figure 2 for plots of the interaction effects.

Lastly, Table 3 shows that the moderated indirect effects examined above have substantial implications for the total effect of service expectations on service satisfaction. Depending on the level of ability to evaluate and motivation to evaluate the total effect of service expectations on service satisfaction is either significantly positive (suggesting a predominance of the placebo effect) or insignificant (suggesting that the placebo effect and the disconfirmation effect balance each other out). 
Insert Figure 2 about here

\section{Supplemental Analysis}

To provide a further test of our theoretical argument that the effect of service expectations on perceived service performance depends on customers' type of information processing, we also asked customers to evaluate to what extent they processed the movie systematically. To this end, we used the following items (Chaiken 1980; Smerecnik et al. 2012): (1) "I followed the movie very actively,” (2) “I processed the movie very accurately," and (3) “I digested the movie very intensively” ( $M=5.157, \mathrm{SD}=1.322)$. The construct achieved adequate reliability $(\alpha=.803$, $\mathrm{AVE}=.627, \mathrm{CR}=.830$ ). We then entered this construct in our path model, replacing our previous moderators ability and motivation to evaluate. Results are depicted in Table 4 and show that systematic information processing, as expected, negatively moderates the effect of service expectations on perceived service performance $(\beta=-.188, \mathrm{p}<.01)$. Furthermore, Table 3 includes results of a floodlight analysis (Spiller et al. 2013). As expected, the total effect of service expectations on service satisfaction strongly depends on the level of systematic information processing: It is positive for low to medium levels of systematic information processing and negative for high levels of systematic information processing. This provides further evidence that the type of information processing is a major influence on the effect of customers' expectations in satisfaction formation.

It is important to mention, that our measure of systematic processing may be more likely to be more positive when customers were enjoying the movie and were thus engaged in it. In fact, the measure of systematic information processing is positively correlated with both perceived service performance $(r=.48)$ and service satisfaction $(r=.51)$. Hence, beyond moderating the service expectations-perceived service performance linkage, systematic 
information may itself be an antecedent of perceived service performance and service satisfaction.

\section{Discussion of Study 1}

Study 1 shows that service expectations have a direct negative effect on service satisfaction (through disconfirmation), but at the same time increase service satisfaction via perceived service performance (through the placebo effect). This latter effect is weaker if customers process the service experience systematically.

Study 1 exhibits two limitations which motivate our subsequent study. First, a contextual limitation of Study 1 is the unconventional relationship between the service provider (i.e. the movie theater) and the service (i.e. the movie). Specifically, as a movie theater has no influence on the performance of a particular movie, Study 1 did not truly test service expectations, but expectations of a movie viewed at a service facility. Similarly, customers did not truly assess perceived service performance, but rather the valence of the movie. In Study 2 we intend to replicate our findings in a purer service context with improved conceptualizations of service expectations and perceived service performance.

Second, a methodological limitation of Study 1 is that it may be prone to a selection bias. Specifically, our sample comprised only customers who had decided to watch a movie and thus most likely held favorable expectations of the movie. To test for selection effects, we estimated an additional model which we only included movies with expectation levels below the median expectation level of 5.8 (see Model 2 in Table 2). Results are largely in line with our full model, which provides some evidence that selection bias may not be major issue. To fully rule out that our findings are unduly influenced by selection effects, in Study 2 we set out to replicate our key findings using an experiment with a randomized selection of participants. 


\section{Study 2: How Does Ability to Evaluate Moderate the Expectation-Satisfaction Linkage?}

\section{Method}

Design. To address the limitation of Study 1 outlined above, we conducted a simulated scenariobased experiment in which we manipulated customers' service expectations. Furthermore, we manipulated participants' type of information processing by enhancing or restricting their ability to evaluate the service. Thus, the study comprised a 2 (service expectations: high vs. low) $\times 2$ (ability to evaluate: high vs. low) between-subjects experiment. We recruited an online convenience sample of 129 participants (average age of 29 years, 62\% female) and randomly allocated the participants to the four experimental conditions. Drawing on prior service research we chose a restaurant visit as the study’s context (Hamer, Liu, and Sudharshan 1999; Oliver and Burke 1999).

Experimental procedure. Participants were informed that they planned a restaurant visit with a friend and were asked to read online reviews about the restaurant. We used these reviews to manipulate participants' expectations of the service performance. Therefore, in the high (low) expectations group, participants read three reviews commending (criticizing) the competence of the restaurant's staff. Our decision to use competence as an indicator of the service performance is based on Homburg, Koschate, and Hoyer (2005), who established that competence is a critical aspect of a restaurant's service performance.

After having read the online reviews, participants watched a video of a restaurant visit displaying two guests from a third-person perspective. The video had the duration of 1 minute and 50 seconds and showed a typical interaction with a waitress during a restaurant visit, that is, the welcoming, ordering, serving, and paying. 
To manipulate the degree of customers' ability to evaluate, participants received specific instructions prior to watching the video. In the high ability to evaluate condition, participants were instructed to pay close attention to the video. Additionally, in the middle of the video we included a 15 second break in which participants were asked to process what they had seen. In the low ability to evaluate condition, we used a procedure based on Campbell (2007) and Shiv and Fedorikhin (1999). Specifically, we asked participants to count the number of eye contacts between the two guests, hereby restricting participants’ cognitive capacity to process the service experience. After viewing the video, we asked participants to evaluate a set of variables.

All manipulations worked as intended. Participants had significantly higher service expectations of the waitress's competence in the high service expectation condition than in the low service expectation condition $\left(\mathrm{M}_{\text {low service expectations }}=3.167, \mathrm{M}_{\text {high service expectations }}=5.159 ; \mathrm{F}(1\right.$, $127)=46.835, \mathrm{p}<.01)$. Furthermore, participants reported a significantly higher level of systematic information processing in the high ability to evaluate condition than in the low ability to evaluate condition $\left(\mathrm{M}_{\text {low ability to evaluate }}=3.419, \mathrm{M}_{\text {high ability to evaluate }}=5.104 ; \mathrm{F}(1,127)=38.535\right.$, $\mathrm{p}<.01)$. Lastly, participants viewed the setting as authentic and realistic $(\mathrm{M}=5.10)$ and were not able to guess the hypotheses correctly.

\section{Measures}

As established in prior experimental research, we used a dummy-variable coding approach to include the experimental treatments as the independent variables in the model estimation (Bagozzi 1977). That is, we coded one dummy variable for service expectations ( $0=$ low service expectations vs. 1= high service expectations) and another dummy-variable for ability to evaluate $(0=$ low ability to evaluate vs. $1=$ high ability to evaluate). Our key dependent variables 
are perceived service performance, service satisfaction, and loyalty to the service provider. Please refer to the Appendix for specifics on the measures.

\section{Model Estimation and Results}

To examine $\mathrm{H}_{1}$ through $\mathrm{H}_{4}$, we estimated the moderated mediation model depicted in Figure 1 using the PROCESS macro in SPSS (e.g., Hayes and Preacher 2014). That is, we estimated a model linking the service expectations dummy to perceived service performance, moderated by the ability to evaluate dummy. We furthermore linked both the service expectations dummy and perceived service performance to service satisfaction. Table 4 displays the results, which we interpret in the following.

In $\mathrm{H}_{1}$ we proposed that service expectations positively affect perceived service performance, which is confirmed $(\mathrm{b}=.581, \mathrm{p}<.05)$. Furthermore, $\mathrm{H}_{2}$ receives some support, which posited that service expectations negatively affect service satisfaction $(b=-.437, p=$ .057). In $\mathrm{H}_{3}$, we proposed that perceived service performance positively affects service satisfaction, which is also supported $(\mathrm{b}=.431, \mathrm{p}<.01)$.

In $\mathrm{H}_{4}$, we proposed that the indirect effect of service expectations on service satisfaction via perceived service performance is weakened if customers have a high ability to evaluate. The interaction effect of service expectations and ability to evaluate on perceived service performance is significantly negative $(b=-.928$, $\mathrm{p}<.05$, please refer to Figure 3 for an interaction plot). To examine whether this interaction effect translates into a moderated mediation as hypothesized in $\mathrm{H}_{4}$, the lower part of Table 4 depictes the indirect effect of service expectations on service satisfaction via perceived service performance. For low ability to evaluate, results reveal a significantly positive indirect effect $(b=.250$; $95 \%$ confidence interval: .033 to .551). For high ability to evaluate, however, the indirect effect of service expectations on 
service satisfaction via perceived service perfromance is insignificant $(b=-.149 ; 95 \%$

confidence interval: -.361 to .051). Confirming $\mathrm{H}_{4}$, these results suggest that the indirect effect of service expectations on service satisfaction via perceived service performance is weakened if customers have a high ability to evaluate. Lastly, as expected, service satisfaction is positively correlated with loyalty to the service provider $(\mathrm{r}=.714, \mathrm{p}<.01)$.

Insert Table 4 about here

Insert Figure 3 about here

\section{Discussion of Study 2}

In line with Study 1, Study 2 provides evidence for the ambivalent role of customers' service expectations on satisfaction formation. While high service expectations are more difficult to meet and thus may have a negative direct effect on satisfaction, at the same time they may have a positive impact on satisfaction through their placebo effect on customers' perceptions of the service performance. Results further confirm our finding of Study 1 that the placebo effect is highly contingent on customers’ ability to evaluate.

Study 2 substantiates our previous results by replicating Study 1 while addressing Study 1's limitations. Specifically, unlike Study 1, Study 2 examined our hypotheses in a pure service context in which the service provider has full control over service performance. Furthermore, by experimentally manipulating service expectations in a fully randomized design, Study 2 helps alleviate concerns of a potential selection bias in Study 1.

Both Studies 1 and 2, however, possess one key limitation which we aim to address in our final Study 3. Specifically, in Studies 1 and 2, the dependent variables were subjective customer attitudes measured through survey scales, i.e., service satisfaction and customer loyalty to the service provider. We were therefore unable to test whether the contingent effects of service 
expectations manifest in objective financial outcomes. We regard this question as essential because our findings only entail implications for managerial practice if the identified effects impact real life business outcomes. Therefore, our primary motivation for Study 3 is to challenge the managerial relevance of our previous findings by examining the interactive effect of customers’ service expectations and motivation to evaluate on objective financial outcomes.

\section{Study 3: Do the Contingent Service Expectation Effects Translate to Real World Financial Data?}

\section{Data Collection and Sample}

We conducted Study 3 in the airline industry, using customer survey data as well as objective revenue data from the company records of a major European airline. Our data collection process was as follows: we first extracted a sample of customers who had booked a flight and surveyed these customers' service expectations before the flight. After the flight, we surveyed customers on their motivation to evaluate the service. Of the 11,416 customers who participated in the preflight survey, 3,963 completed the post-flight survey (response rate of 34.7\%). As the demographics of respondents and non-respondents did not significantly differ, a non-response bias was judged to be unlikely. After exclusion of datasets with missing values, 3,704 datasets remained for our analyses (average age of 47 years, 64\% male).

Following the survey, we collected the sales growth of each customer from company records, i.e., his or her percentage change in revenue for the subsequent 12 months compared to the 12 months up to flight. Sales growth has frequently been used as a measure of customer outcomes (e.g., Wetzel, Hammerschmidt, and Zablah 2014) as it constitutes an easy-access validation of customer loyalty (Morgan and Rego 2006). 


\section{Measures}

Survey measures. To measure motivation to evaluate, we asked customers to what extent they had expended effort when evaluating the flight experience. This measure draws on the notion that processing information systematically is an effortful task that requires high processing capacity (Yoon 1997). Following the airline’s request we measured motivation to evaluate using a single item. To ensure validity despite the use of a single item, the item focused on customers' motivation to evaluate the focal flight experience rather than customers' general predisposition to evaluate (which we had collected in Study 1). Thus, the measure focuses on a concrete object rather than an abstract concept, which is advised when multi-item measurements are not available (Bergkvist and Rossiter 2007).

The items for measuring service expectations are detailed in the Appendix, descriptives and correlations are provided in Table 5. Following the airline's requests to harmonize the survey with existing customer surveys, we used 6-point Likert-type scales. In line with Study 1, we controlled for customers' age, gender, and pre-consumption loyalty. Furthermore, we controlled for customers' membership in the airline’s loyalty program using a dummy variable. We mean-centered service expectations and motivation to evaluate prior to the estimation (Cohen et al. 2003).

Sales growth. As indicated above, we collected each customer's sales growth from company records. The variable shows by which percentage a customer's revenue changed from the 12 months up to focal flight to the 12 months after the focal flight (Morgan and Rego 2006). 


\section{Model Estimation and Results}

In line with our conceptual framework depicted in Figure 1, we regressed sales growth on service expectations, moderated by customers’ motivation to evaluate using Mplus 7 (Muthén and Muthén 2012). Results are depicted in Table 6 and show that neither service expectations nor motivation to evaluate exert a significant main effect on sales growth $(p>.10)$. However, as expected the interaction of service expectations and motivation to evaluate negatively impacts sales growth $(\beta=-.036, \mathrm{p}<.05)$. Please refer to Figure 4 for a plot of the effect of service expectations on sales growth at various values of motivation to evaluate (Spiller et al. 2013). As the figure shows, if motivation to evaluate has a value of 1 , the simple slope of service expectations on sales growth is significantly positive $(\mathrm{p}<.05)$. As motivation to evaluate increases, the effect sign of the simple slope becomes less positive and even negative. However, adopting a significance level of .05, the simple slope never becomes significantly negative-even for a maximum value of motivation to evaluate $(b=-.164, p=.055)$.

Lastly, the Johnson-Neyman value for motivation to evaluate is 1.745 (Spiller et al. 2013). That is, if motivation to evaluate has a value below (above) 1.745, the effect of service expectations on sales growth is significantly positive (insignificant).

Insert Table 6 about here

Insert Figure 4 about here

\section{Discussion of Study 3}

Underlining the predictive and external validity of our previous findings, this study provides evidence that the effect of service expectations on customers' sales growth strongly hinges on customers' motivation to evaluate. If customers lack motivation to evaluate the service, their previously held service expectations increase their sales growth. Conversely, if customers 
possess a high motivation to evaluate, their service expectations leave sales growth unaffected as the disconfirmation effect and the placebo effect balance each other out.

\section{Discussion: Implications for Service Research and Practice}

\section{Research Issues}

Our study shows that customers' service expectations exhibit ambivalent effects on service satisfaction. First, they decrease service satisfaction owing to a disconfirmation effect. Second, they indirectly increase service satisfaction via a placebo effect on perceived service performance. However, this placebo effect is less pronounced the higher customers' ability and motivation to evaluate, which we attributed to customers' higher level of systematic information processing. These findings contribute and open up new research opportunities for four areas of the service literature: (1) service expectation management, (2) service failure and recovery, (3) service design and co-creation, and (4) theoretical frameworks in service expectations research.

Service expectation management. Prior research on the effective management of customers' service expectations in part made countervailing recommendations whether to increase or decrease customer expectations (Boulding, Kalra, and Staelin 1999; Davidow and Uttal 1989). We harmonize these opposing findings by clarifying that service providers should increase service expectations when customers possess low motivation and low ability to evaluate the service and tone expectations down when customers are highly motivated and able to assess the service experience. This result raises the intricate question for future research how service providers should specifically set customer expectations. Service providers may influence customers' expectations of their service performance directly through various communication channels such as advertising, service representatives, or social media applications or more subtly through service ambience, corporate identity or reference marketing. Since the effectiveness of 
these channels for service expectation management should vary considerably, future research should investigate the optimal channel portfolio and conditions which promote the influence of each channel.

Service failure and recovery. Our study contributes to literature on service failures. Works in this field have found that service failures are decisively driven by negative disconfirmation of customers' service expectations, that is, by service performance not meeting customers’ expectations (Bitner, Booms, and Tetreault 1990). Our results suggest that high expectations may not only be a driver of, but also a shield against service failures depending on customers' ability and motivation to evaluate. We thus consider it an interesting avenue for further research to examine the role of a potential placebo effect in the formation of service failure perceptions.

Furthermore, within the service failure literature, our study contributes to research on appropriate service recovery strategies (Gelbrich, Gäthke, and Grégoire 2015). An important determining factor of customers' satisfaction with service recovery is the confirmation of customers' expectations of this recovery (McCollough, Berry, and Yadav 2000). Again, it might be worthwhile to examine a potential role of the placebo effect in this respect.

Service design and co-creation. Our findings likewise hold meaningful implications for research on service design and co-creation (Jaakkola and Alexander 2014). We contribute to this research by showing that service expectation management may constitute an essential step in the design of services. Seeing the significant effects of setting the right customer expectations on service satisfaction formation, research on service design might conceive expectation management as an initial, basic step in the service process. This rather novel view on service design instigates the question how services should be designed to benefit from the service 
expectation placebo effect in the best possible way. Hereby, we consider it as highly interesting for future research to focus on fluency of the service process (e.g., Lee and Labroo 2004) as a design factor that reduces customers' motivation to evaluate and thus promotes the translation of high service expectations to perceived service performance.

In research on service design, co-creation of service innovations of customer and service providers assumes an increasingly prominent role (Haumann et al. 2015). When inspecting service co-creation in the light of our findings on customers' expectations, interesting insights for this literature stream emerge: while naturally service co-creation should raise customers’ expectations towards the service performance, simultaneously, co-creation increases customers' involvement with the service as well as their ability and motivation to evaluate the service, countering a placebo effect. Therefore, we view the role of expectation management in in service co-creation as an important future research endeavor.

Eligible theories for the analysis of service expectations. Our paper also provides implications regarding the suitability of various theoretical frameworks in service expectations research. Results of our studies underline that the contingency of the service expectationsatisfaction linkage is best understood in terms of information processing theory, with customers' ability and motivation to evaluate determining to what extent customers strive for confirming their prior service expectations. Hereby, our studies show that both customers' general predispositions to be motivated and able to evaluate (Study 1) and situationally driven ability and motivation to evaluate (Studies 2 and 3) determine the effect of service expectations on perceived service performance. Alternative frameworks such as the assimilation model (Sherif and Sherif 1967) or the contrast model (Churchill and Suprenant 1982) are incompatible 
with our research: While the assimilation model predicts that the placebo effect necessarily occurs, the contrast model precludes the incidence of the placebo effect.

\section{Limitations}

Our results are subject to limitations which need to be acknowledged. In the following, we outline these limitations and provide avenues for future research.

Study 1. As mentioned previously, Study 1 exhibits two limitations which we sought to address by the subsequent studies. First, concerning the movie context, we did not focus on the service delivered by the movie theater but on customers' reception of the movie itself. Second, as Study 1 focused on customers that attended the movies it is likely that customers previously held favorable expectations towards the movies indicating potential selection effects. To address this limitation, we (1) verified that our findings also hold for low levels of expectations and (2) replicated Study 1 with the randomized experimental design of Study 2.

Study 2. To experimentally induce a high ability to evaluate the service we instructed participants to pay close attention to the video and included a 15 second break in the middle of the video. Our motivation for this step was to free mental resources to foster customers' systematic processing of the video. However, including the break might have introduced a satiation effect in the high ability group (Nelson, Meyvis, and Galak 2009), positively affecting perceived service performance.

Study 3. A limitation of Study 3 is that it did not test the full conceptual model including our hypothesized ambivalent effects of service expectations on service satisfaction. Thus, Study 3 does not provide a rigorous test of our theoretical arguments put forth in our hypotheses. Furthermore, our measure of motivation to evaluate may reflect other constructs such as familiarity with the service. Future research should therefore replicate our findings using a multi- 
item measure or a more objective task-based measure of motivation to evaluate, which we were unable to implement owing to constraints to the data collection imposed by the airline.

\section{Managerial Implications}

Our work provides recommendations (1) in which situations to foster high as compared to low customer service expectations and (2) how to maximize customer satisfaction given certain levels of customer service expectations. First, results indicate that service providers should increase customers' expectations to enhance satisfaction if customers' ability and motivation to evaluate the service is low. Conversely, if customers are apt and motivated to evaluate the service, providers should refrain from setting high expectations as these might afflict customer satisfaction. To follow this recommendation, for service firms the question arises which specific contexts lead to a high as compared to a low customer ability and motivation to evaluate the service. For instance, raising expectations should be highly instrumental in enhancing perceived service performance in low involvement situations where customers do not closely evaluate the service performance. Conversely, in a high involvement context with customers' narrowly focusing on the service, reducing expectations may emerge as more effective.

In this respect, a key managerial challenge pertains to how specifically to manage customers' service expectations to the appropriate level. While service providers might in principal employ all available communication channels to set customer expectations such as advertising, frontline employees, or corporate webpages, we propose social media to assume a particularly powerful role in service expectation management. This is because whether customers adapt their service expectations in response to new information on the service should critically depend on the credibility of the information source. In the light of the rising consumer skepticism (e.g., Ford, Smitz, and Swasy 1990) against firm communications, customers may discount 
advertising or frontline employee claims designed to manage their expectations whereas social media may exhibit a distinctly better standing. For instance, consumer reviews are nearly 12 times more trusted than manufacturers’ descriptions (eMarketer 2010). Therefore, service firms may encourage customers' sharing of service experiences online with peers and provide the necessary online platforms or mobile applications. In this vein, service providers may guide customers to focus on positive aspects to set high expectations or balance positive and negative aspects to tone expectations down.

Second, service providers should proactively track (e.g., through surveys) whether customers approach the service delivery with high or low expectations. If customers harbor low service performance expectations, for instance, due to the provider's reputation, to prevent that low expectations spoil customers’ perceived service importance, firms should foster customers’ ability and motivation to evaluate the service. To this end, we derive three specific recommendations from our study: (1) To increase customers’ ability to evaluate the service experience, providers might repeatedly track customers’ satisfaction with assessable service elements across the entire service process. For instance, for each step of the service process service employees might be instructed to inquire customers' satisfaction. (2) Service providers may also facilitate customers' ability to evaluate the service experience by providing concrete goals and deliverables for each service process step against which customers may rate service performance. (3) To increase customers' motivation to evaluate the service experience, prior to the service experience, service providers might instill an "evaluation-oriented mindset” into customers by incentivizing or asking customers for their feedback on the service process. (4) Service providers may enhance customers' motivation to evaluate the service experience by 
fostering strong service employee-customer interaction and involving customers in decisions throughout the service process.

On the contrary, if customers approach the service delivery with high expectations, firms should take actions to decrease the likelihood that customers overly focus on service performance and profit from the positive spillover effect of high expectations on service performance perceptions and consecutively customer satisfaction. For this purpose, we recommend service providers to design their services processes as fluent and smooth as possible by minimizing delays and overall duration of the service process as well as avoiding excessively involving customers. 
TABLE 1

Descriptive Statistics and Correlations (Study 1)

\begin{tabular}{|c|c|c|c|c|c|c|c|c|c|}
\hline Variable & & M & SD & V1 & V2 & V3 & V4 & V5 & V6 \\
\hline V1: Service expectations & $(t=1)$ & 5.695 & 1.326 & 1 & & & & & \\
\hline V2: Perceived service performance & $(\mathrm{t}=2)$ & 6.033 & 1.151 & $.223^{\star \star *}$ & 1 & & & & \\
\hline V3: Service satisfaction & $(\mathrm{t}=2)$ & 5.965 & 1.291 & $.119 * *$ & $.802^{\star \star *}$ & 1 & & & \\
\hline V4: Loyalty to the service provider & $(\mathrm{t}=2)$ & 5.987 & 1.288 & $.106^{\star}$ & $.268^{\star \star \star}$ & $.337^{\star \star \star}$ & 1 & & \\
\hline V5: Ability to evaluate & $(\mathrm{t}=2)$ & 5.748 & 1.075 & .009 & .020 & .008 & $.094^{*}$ & 1 & \\
\hline V6: Motivation to evaluate & $(t=2)$ & 5.251 & 1.070 & .021 & $.116^{\star \star}$ & .076 & $.099 *$ & $.292^{\star \star \star}$ & 1 \\
\hline
\end{tabular}

Note: $\mathrm{M}=$ Mean, $\mathrm{SD}=$ Standard Deviation 
TABLE 2

Estimated Path Coefficients (Study 1)

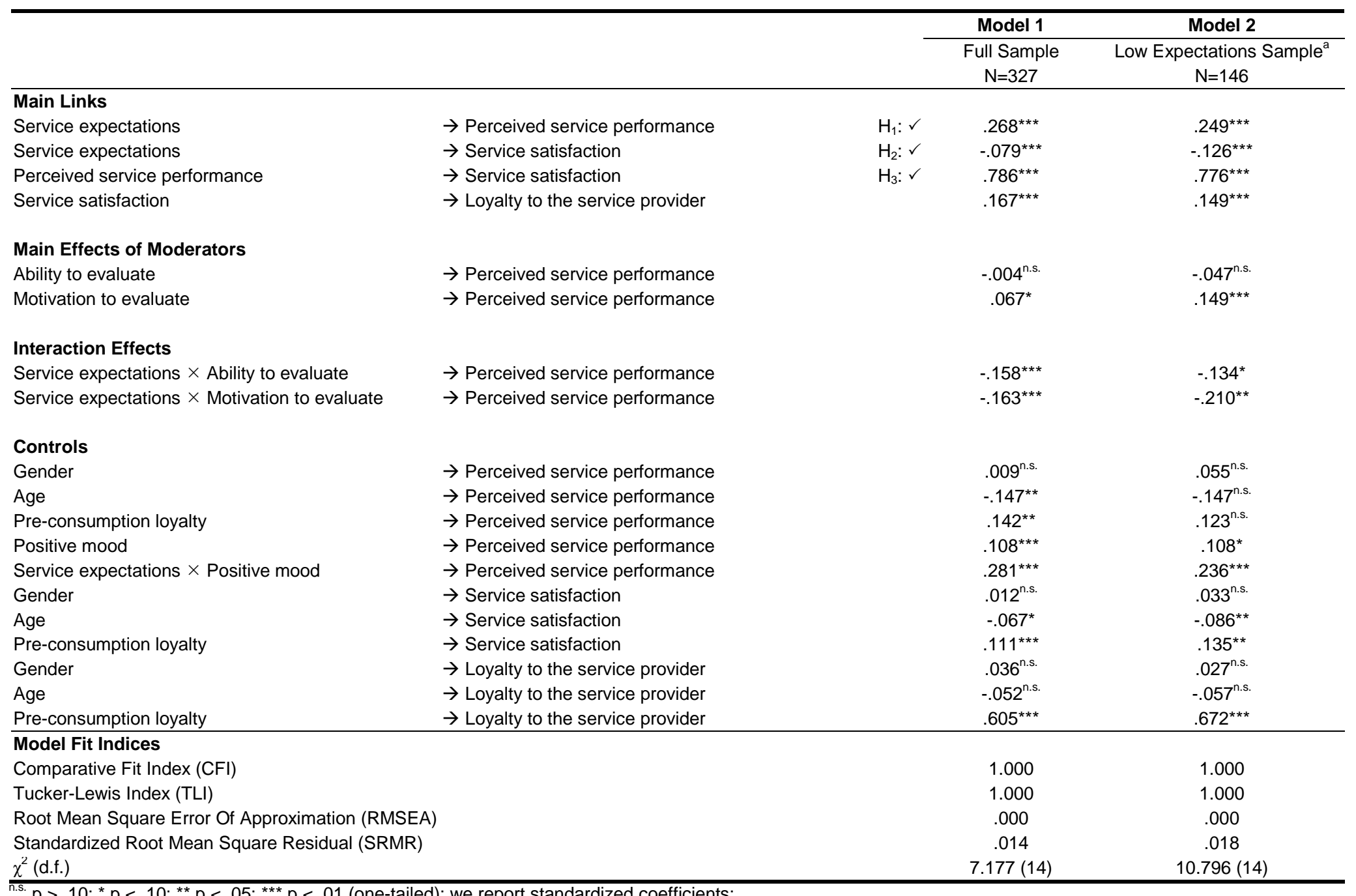

the (one-tailed); we report standardized coefficients; 
TABLE 3

Floodlight Analysis ${ }^{\mathrm{a}}$ (Study 1)

\begin{tabular}{|c|c|c|c|c|c|c|}
\hline Moderator & Value & $\begin{array}{l}\text { Direct Conditional Effect } \\
\text { of Service Expectations } \\
\text { on Perceived Service } \\
\underline{\text { Performance }}\end{array}$ & $\begin{array}{c}\text { Indirect Effect of Service } \\
\text { Expectations on Service } \\
\text { Satisfaction via } \\
\text { Perceived Service } \\
\text { Performance }\end{array}$ & $\begin{array}{c}\text { Direct Effect of Service } \\
\text { Expectations on Service } \\
\text { Satisfaction }\end{array}$ & $\begin{array}{c}\text { Total Effect of Service } \\
\text { Expectations on Service } \\
\text { Satisfaction }\end{array}$ & Implication \\
\hline \multirow{6}{*}{$\begin{array}{l}\text { Ability to } \\
\text { evaluate }\end{array}$} & 1 & $.947^{\star \star \star}$ & $.744^{\star \star \star}$ & $-.079 * \star \star$ & $.665^{\star *}$ & \multirow{6}{*}{$\begin{array}{c}\mathrm{H}_{4}: \checkmark \\
\text { Johnson-Neyman value } \\
6.850\end{array}$} \\
\hline & 2 & $.804^{\star \star \star}$ & $.632^{\star \star \star}$ & $-.079^{\star \star \star}$ & $.553^{\star \star}$ & \\
\hline & 3 & $.660^{\star \star *}$ & 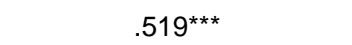 & $-.079 * \star \star$ & $.440^{\star \star \star}$ & \\
\hline & 4 & $.517^{\star \star \star}$ & $.407^{\star \star \star}$ & $-.079^{\star \star \star}$ & $.328^{\star \star \star}$ & \\
\hline & 6 & $.231^{\star \star \star}$ & $.177^{\star \star \star}$ & 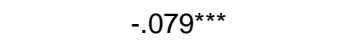 & $.100^{\star *}$ & \\
\hline & 7 & $.088^{\text {n.s. }}$ & $.070^{\text {n.s. }}$ & $-.079^{\star \star \star}$ & $-.009^{\text {n.s. }}$ & \\
\hline \multirow{6}{*}{$\begin{array}{l}\text { Motivation } \\
\text { to evaluate }\end{array}$} & 1 & $.890^{\star \star \star}$ & $.700^{\star \star \star}$ & $-.079 * \star \star$ & $.621^{\star \star \star}$ & \multirow{6}{*}{$\begin{array}{l}\text { Johnson-Neyman value } \\
6.208\end{array}$} \\
\hline & 2 & $.744^{\star \star \star}$ & $.585^{\star \star \star}$ & $-.079 \star \star \star$ & $.506^{\star \star \star}$ & \\
\hline & 3 & $.597^{\star \star \star}$ & $.470^{\star \star \star}$ & $-.079 * \star \star$ & $.391^{\star \star \star}$ & \\
\hline & 4 & $.451^{\star \star *}$ & $.354^{\star \star \star}$ & $-.079 * \star \star$ & $.275^{\star \star \star}$ & \\
\hline & 5 & $.304^{\star \star \star}$ & $.239 * \star \star$ & 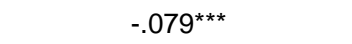 & $.160^{\star \star \star}$ & \\
\hline & 6 & $.158^{\star \star \star}$ & $.121^{\star \star \star}$ & $-.079^{\star \star *}$ & $.044^{\text {n.s. }}$ & \\
\hline \multirow{7}{*}{$\begin{array}{l}\text { Systematic } \\
\text { information } \\
\text { processing } \\
\text { (supple- } \\
\text { mental } \\
\text { analysis) }\end{array}$} & 1 & $.777^{* \star \star}$ & $.611^{\star \star \star}$ & $-.079^{* \star *}$ & $.532^{\star \star \star}$ & \multirow{7}{*}{$\begin{array}{c}\text { Johnson-Neyman value }{ }^{b} \\
5.574\end{array}$} \\
\hline & 2 & $.628^{\star \star \star}$ & $.493^{\star \star \star}$ & $-.079 \star \star \star$ & $.414^{\star \star \star}$ & \\
\hline & 3 & $.478^{\star \star \star}$ & $.366^{\star \star \star}$ & $-.079 \star \star \star$ & $.289^{\star \star \star}$ & \\
\hline & 4 & $.285^{\star \star \star}$ & $.251^{\star \star \star}$ & $-.079^{\star \star \star}$ & $.174^{\star \star \star}$ & \\
\hline & 5 & $.179^{\star \star \star}$ & $.141^{\star \star \star}$ & 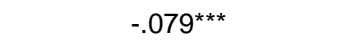 & $.062^{\star *}$ & \\
\hline & 6 & $.030^{\text {n.s. }}$ & $.023^{\text {n.s. }}$ & $-.079 * \star \star$ & $-.056^{\star}$ & \\
\hline & 7 & $-.120^{\star}$ & $-.094^{\star}$ & 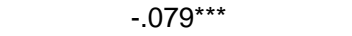 & $-.173^{\star \star \star}$ & \\
\hline
\end{tabular}

.s. $p>.10 ;{ }^{*} p<.10 ;{ }^{* *} p<.05 ; * \star * p<.01$ (one-tailed); we report standardized coefficients.

${ }^{a}$ On the basis of Spiller et al. (2013); ${ }^{b}$ Pertains to the value of the respective moderator at which the indirect effect of service expectations on service satisfaction via perceived service performance is significant at the .05 level (Spiller et al. 2013). 
TABLE 4

Supplemental Analysis to Verify Results with a Systematic Processing Measure (Study 1)

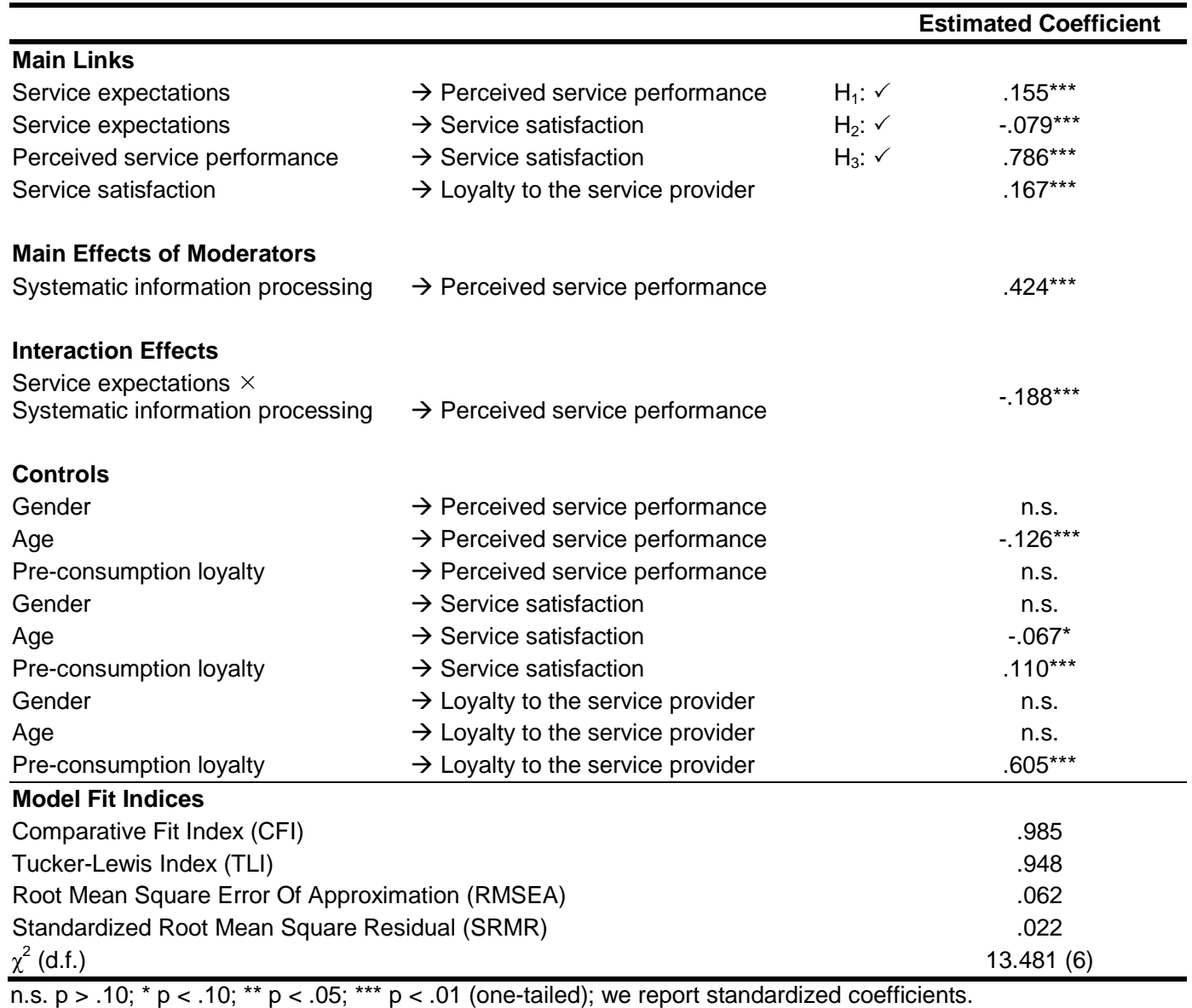

n.s. $p>.10 ;{ }^{\star} p<.10 ;{ }^{\star \star} p<.05 ;{ }^{\star \star \star} p<.01$ (one-tailed); we report standardized coefficients. 
TABLE 5

Estimated Coefficients using the PROCESS Macro ${ }^{\text {a }}$ (Study 2)

\begin{tabular}{|c|c|c|c|c|}
\hline \multicolumn{5}{|c|}{ Estimated Regression Coefficients } \\
\hline \multirow[b]{2}{*}{ Independent Variables } & & \multicolumn{3}{|c|}{ Dependent Variable } \\
\hline & & \multicolumn{2}{|c|}{ Perceived Service Performance } & Service Satisfaction \\
\hline Perceived service performance & & \multicolumn{2}{|r|}{-} & $.431^{* \star *}$ \\
\hline Service expectations & & \multicolumn{2}{|r|}{$.581^{\star \star}$} & $-.437^{\star}$ \\
\hline Ability to evaluate & & \multicolumn{2}{|r|}{$.633^{\star *}$} & $.116^{\text {n.s. }}$ \\
\hline Service expectations $\times$ Ability to ev & uate & \multicolumn{2}{|r|}{$-.928 * \star$} & $-.071^{\text {n.s. }}$ \\
\hline \multicolumn{5}{|c|}{ Conditional Indirect Effects } \\
\hline Indirect Effect & $\begin{array}{c}\text { Value of } \\
\text { Ability to Evaluate }^{b}\end{array}$ & Effect & $\begin{array}{l}\text { Lower Limit of the } 95 \% \\
\text { Confidence Interval }\end{array}$ & $\begin{array}{l}\text { Upper Limit of the } 95 \% \\
\text { Confidence Interval }\end{array}$ \\
\hline \multirow{2}{*}{$\begin{array}{l}\text { Service expectations } \\
\rightarrow \text { perceived service performance } \\
\rightarrow \text { service satisfaction }\end{array}$} & $\begin{array}{c}0, \\
\text { that is, } \\
\text { low ability to evaluate }\end{array}$ & .250 & .033 & .551 \\
\hline & $\begin{array}{c}1, \\
\text { that is, } \\
\text { high ability to evaluate }\end{array}$ & -.149 & -.361 & .051 \\
\hline
\end{tabular}


TABLE 6

Descriptive Statistics and Correlations (Study 3)

\begin{tabular}{lccccc}
\hline Variable & M & SD & V1 & V2 & V3 \\
\hline V1: Sales growth & .123 & 2.218 & 1 & & \\
V2: Service expectations & 4.394 & .835 & -.021 & 1 & \\
V3: Motivation to evaluate & 2.871 & 1.517 & .015 & $-.078^{*}$ & 1 \\
\hline * $<.01$ (two-tailed) & & & & & \\
Note: $\mathrm{M}=$ Mean, SD = Standard Deviation & & & & &
\end{tabular}


TABLE 7

Validation with Objective Customer Revenue Data: Estimated Coefficients (Study 3)

\begin{tabular}{lc}
\hline & Dependent Variable \\
\cline { 2 - 2 } Independent Variable & Sales Growth \\
\hline Main Effects & $.010^{\text {n.s. }}$ \\
Service expectations & $.018^{\text {n.s. }}$ \\
Motivation to evaluate & \\
Interaction Effect & $-.036^{\star \star}$ \\
Service expectations $\times$ Motivation to evaluate & $.026^{\star}$ \\
Controls & $-.037^{\star \star}$ \\
Age & $-.029^{\star}$ \\
Gender & $.113^{\star \star \star}$ \\
Pre-consumption loyalty & Loyalty program membership \\
\hline n.s. $p>.10,{ }^{*} p<.10,{ }^{\star \star} p<.05,{ }^{\star \star \star} p<.01$ (one-tailed); we report standardized coefficients.
\end{tabular}


FIGURE 1

Conceptual Framework: The Ambivalent Role of Service Expectations in Service Satisfaction Formation

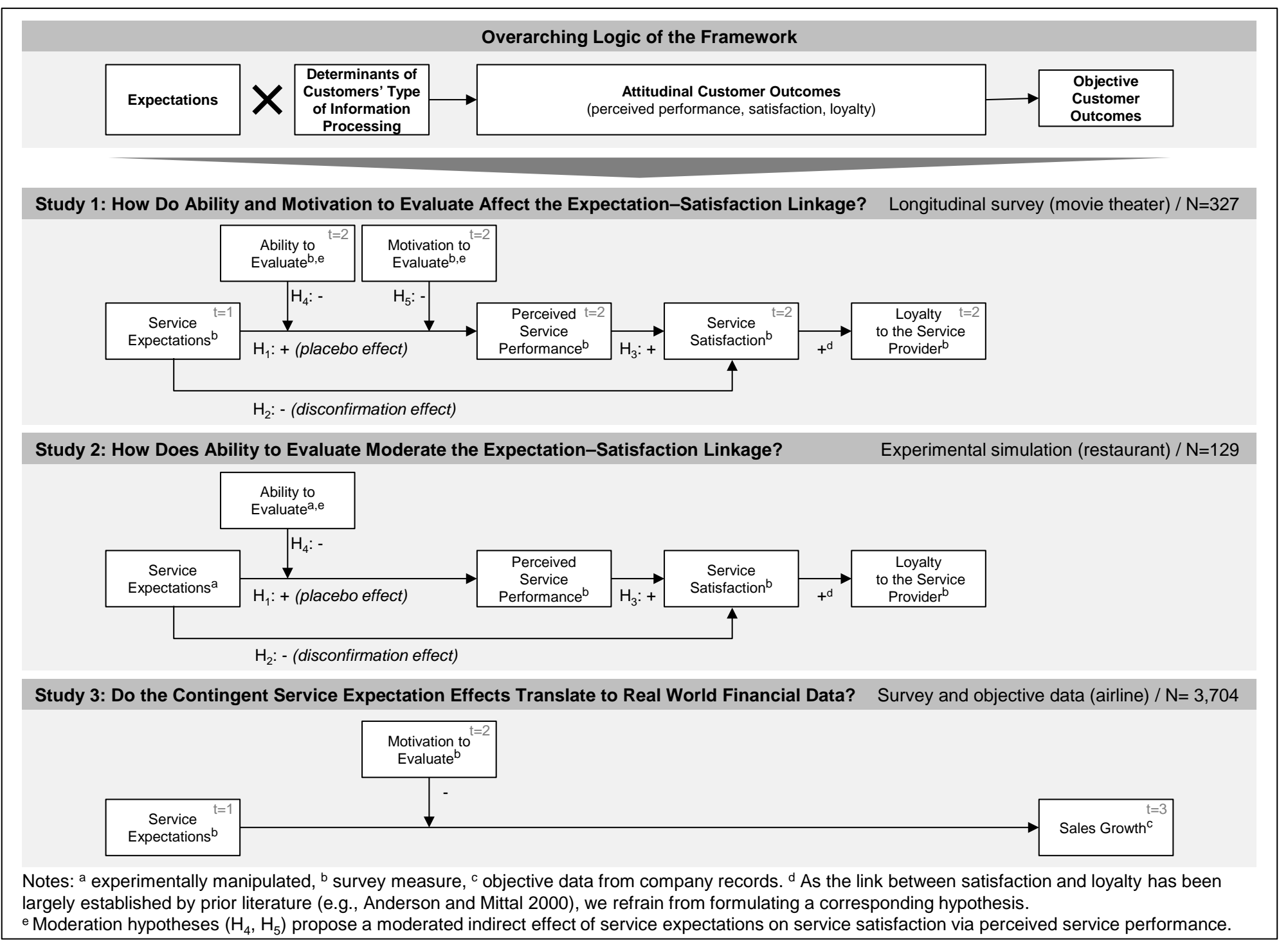


FIGURE 2

Interactive Effect of Service Expectations and Ability as well as Motivation to Evaluate on Perceived Service Performance (Study 1)

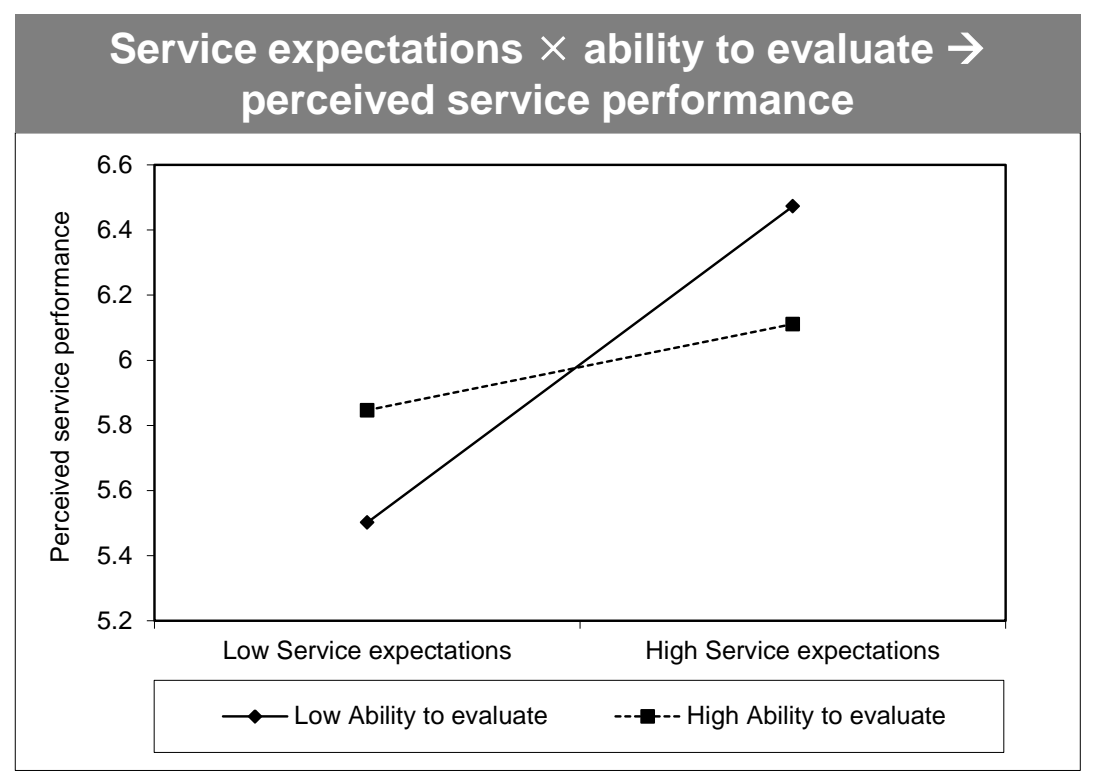

\section{Service expectations $\times$ motivation to evaluate $\rightarrow$ perceived service performance}

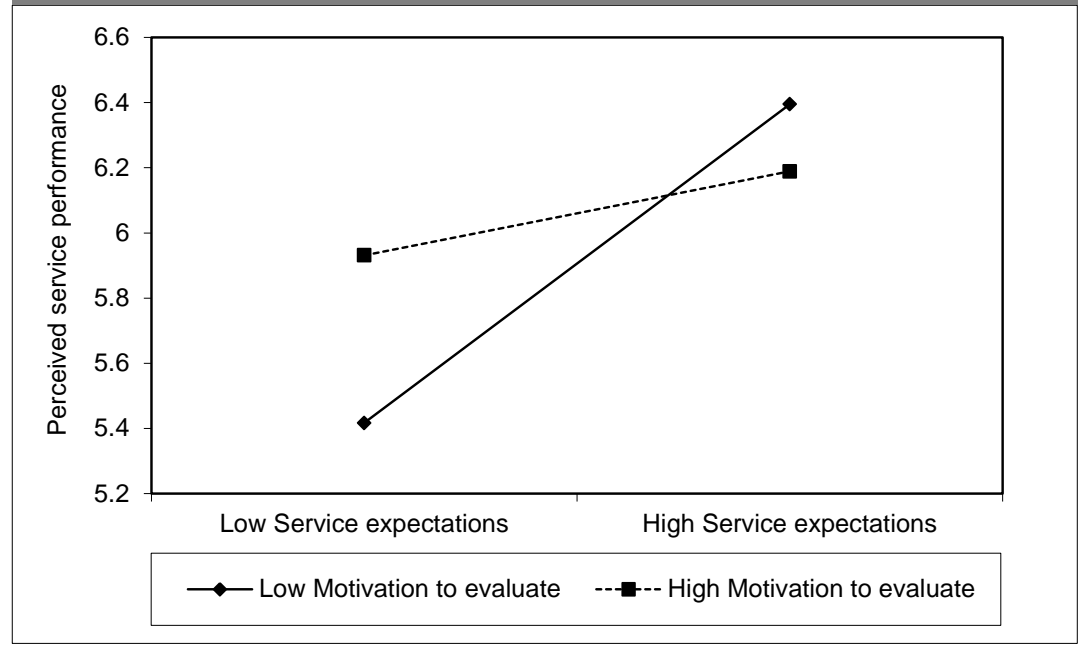

Note: A low (high) degree pertains to a value of one standard deviation below (above) the mean value of the variable. 
FIGURE 3

Interactive Effect of Service Expectations and Ability to Evaluate on Perceived Service Performance (Study 2)

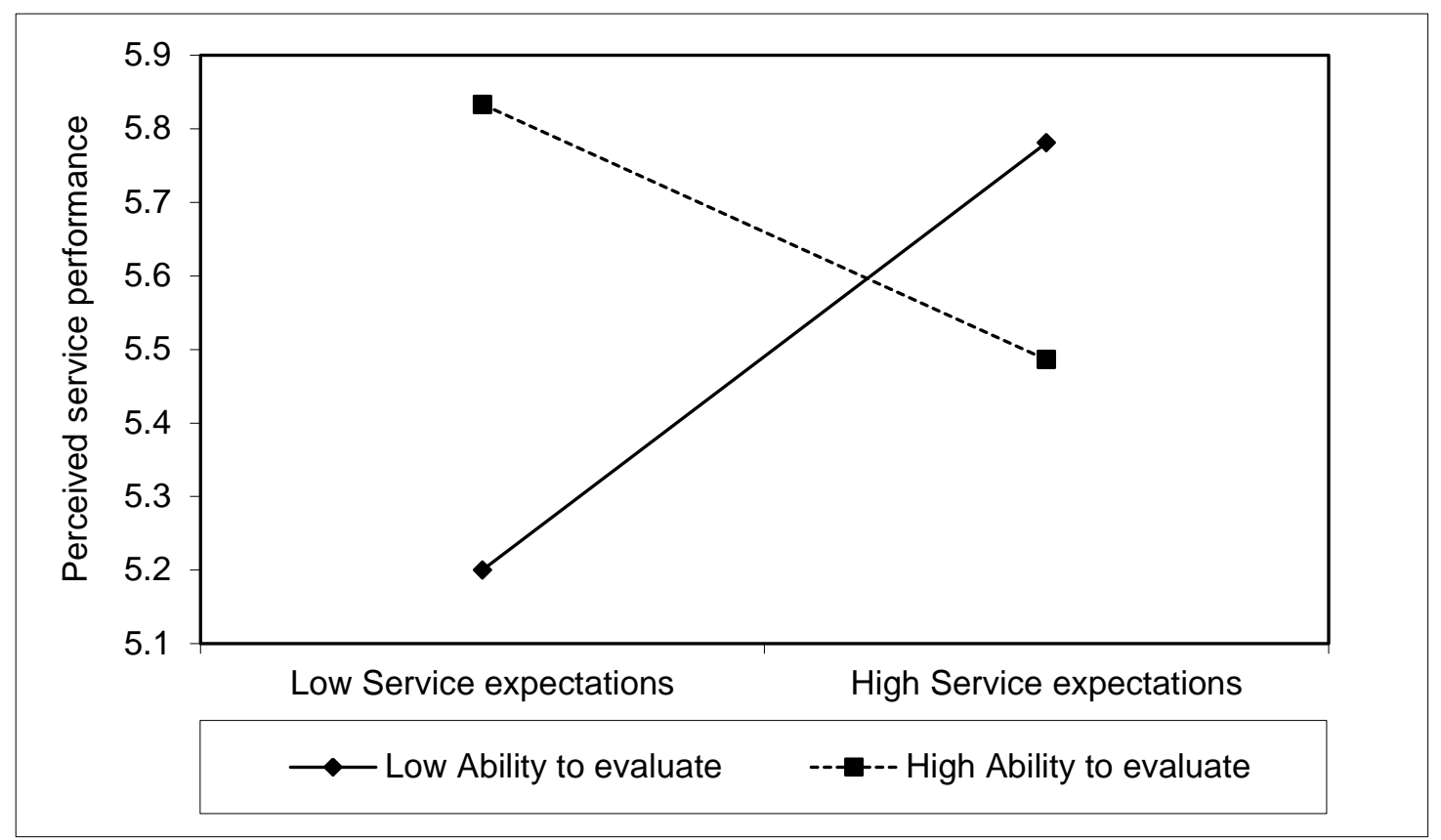


FIGURE 4

Interactive Effect of Service Expectations and Motivation to Evaluate on Sales Growth (Study 3)

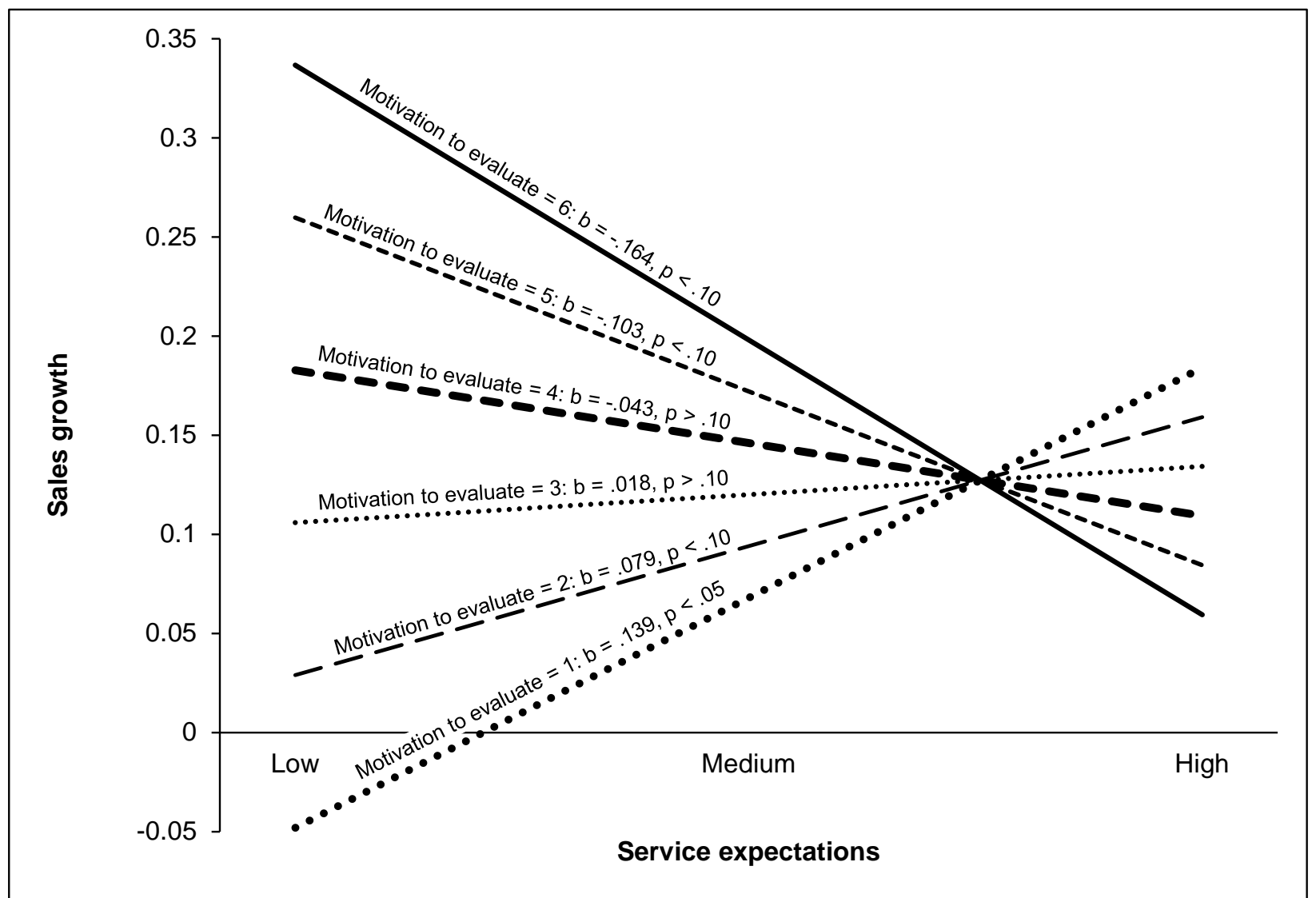

Note: Plot of a floodlight analysis on the basis of Spiller et al. (2013). A low (high) degree of service expectations pertains to a value of one standard deviation below (above) the mean value of service expectations. 


\section{APPENDIX \\ Measures and Psychometric Properties}

\begin{tabular}{|c|c|c|c|c|c|}
\hline & Definition & $\begin{array}{l}\text { Factor } \\
\text { Loading }\end{array}$ & $\alpha$ & CR & AVE \\
\hline \multicolumn{6}{|l|}{ Study 1} \\
\hline \multicolumn{6}{|c|}{$\begin{array}{l}\text { Service expectations (based on Fornell et al. 1996), } \\
\text { 7-point Likert-type scale: "fully disagree" to "fully agree", collected before the movie }\end{array}$} \\
\hline $\begin{array}{l}\text { I believe that I will perceive this as a high-quality movie. } \\
\text { I believe that I will really like the movie. } \\
\text { I believe that the movie will be high-quality entertainment. }\end{array}$ & $\begin{array}{l}\text { A customer's prediction on } \\
\text { what an offering is going to } \\
\text { deliver (Golder, Mitra, and } \\
\text { Moorman 2012) }\end{array}$ & $\begin{array}{l}.88 \\
.96 \\
.87\end{array}$ & .93 & .93 & .82 \\
\hline \multicolumn{6}{|c|}{$\begin{array}{l}\text { Perceived service performance (based on Fornell et al. 1996), } \\
\text { 7-point Likert-type scale: "fully disagree" to "fully agree", collected after the movie }\end{array}$} \\
\hline $\begin{array}{l}\text { I perceived this as a high-quality movie. } \\
\text { I really liked the movie. } \\
\text { The movie was high-quality entertainment. }\end{array}$ & $\begin{array}{l}\text { A customer's subjective } \\
\text { evaluation of a service } \\
\text { (McKinney, Yoon, and Zahedi } \\
\text { 2002) }\end{array}$ & $\begin{array}{l}.80 \\
.95 \\
.89\end{array}$ & .91 & .91 & .78 \\
\hline \multicolumn{6}{|c|}{$\begin{array}{l}\text { Service satisfaction (based on Voss, Parasuraman, and Grewal 1998), } \\
\text { 7-point Likert-type scale: "fully disagree" to "fully agree", collected after the movie }\end{array}$} \\
\hline $\begin{array}{l}\text { I was very satisfied with the movie. } \\
\text { I am very satisfied with my movie choice. } \\
\text { I was very satisfied with the movie's quality. }\end{array}$ & $\begin{array}{l}\text { Extent to which a customer is } \\
\text { pleased with a service (Oliver } \\
\qquad 1980 \text { ) }\end{array}$ & $\begin{array}{l}.93 \\
.91 \\
.83\end{array}$ & .92 & .92 & .79 \\
\hline \multicolumn{6}{|c|}{$\begin{array}{l}\text { Loyalty to the service provider I pre-consumption loyalty (based on Johnson, } \\
\text { Herrmann, and Huber 2006), 7-point Likert-type scale: "fully disagree" to "fully agree", } \\
\text { collected after / before the movie }\end{array}$} \\
\hline $\begin{array}{l}\text { I will watch further movies in this theater. } \\
\text { I will recommend this movie theater to my friends. } \\
\text { I will revisit this movie theater. }\end{array}$ & $\begin{array}{l}\text { A customer's commitment to } \\
\text { repurchase from or } \\
\text { repatronize the provider of a } \\
\text { service (Oliver 1980) }\end{array}$ & $\begin{array}{l}.92 / .94 \\
.68 / .74 \\
.86 / .92\end{array}$ & $.85 / .89$ & $.86 / .90$ & $.68 / .76$ \\
\hline \multicolumn{6}{|c|}{$\begin{array}{l}\text { Ability to evaluate (based on Petty and Caciopoppo 1986; Kopalle and Lehmann 2001), } \\
\text { 7-point Likert-type scale: "fully disagree" to "fully agree", collected after the movie }\end{array}$} \\
\hline $\begin{array}{l}\text { I notice when product performance does not match the } \\
\text { quality I expect from the product. } \\
\text { I realize when product performance does not match my } \\
\text { prior expectations. }\end{array}$ & $\begin{array}{l}\text { Extent to which a customer is } \\
\text { capable of assessing service } \\
\text { performance }\end{array}$ & - & .90 & - & - \\
\hline \multicolumn{6}{|c|}{$\begin{array}{l}\text { Motivation to evaluate (based on Jarvis and Petty 1996), } \\
\text { 7-point Likert-type scale: "fully disagree" to "fully agree", collected after the movie }\end{array}$} \\
\hline $\begin{array}{l}\text { I want to know exactly what is good and bad about } \\
\text { everything. }\end{array}$ & & .71 & .82 & .83 & .63 \\
\hline I like to decide that new things are really good or really bad. & $\begin{array}{l}\text { Extent to which a customer } \\
\text { engages in evaluative }\end{array}$ & 66 & & & \\
\hline I pay a lot of attention to whether things are good or bad. & $\begin{array}{l}\text { responding (Jarvis and Petty } \\
\text { 1996) }\end{array}$ & .97 & & & \\
\hline \multicolumn{6}{|l|}{ Age, open text box, collected after the movie } \\
\hline How old are you? & - & - & - & - & - \\
\hline \multicolumn{6}{|c|}{ Gender, check box: "male", "female", collected after the movie } \\
\hline What is your gender? & - & - & - & - & - \\
\hline \multicolumn{6}{|c|}{$\begin{array}{l}\text { Positive mood (based on Thompson 2007), } \\
\text { 7-point Likert-type scale: "fully disagree" to "fully agree", collected before the movie }\end{array}$} \\
\hline $\begin{array}{l}\text { At the moment, I feel happy. } \\
\text { At the moment, I feel satisfied. } \\
\text { At the moment, I feel bad-tempered (reverse-coded). }\end{array}$ & $\begin{array}{l}\text { Extent to which a customer is } \\
\text { in a good temper when } \\
\text { consuming a service }\end{array}$ & $\begin{array}{l}.92 \\
.83 \\
.71\end{array}$ & .86 & .86 & .68 \\
\hline \multicolumn{6}{|l|}{ Study 2} \\
\hline \multicolumn{6}{|l|}{ Service expectations } \\
\hline $\begin{array}{l}\text { Experimentally manipulated; dummy variable }(0=\text { low } \\
\text { service expectations; } 1=\text { high service expectations })\end{array}$ & See Study 1 & - & - & - & - \\
\hline
\end{tabular}

Ability to evaluate 
Experimentally manipulated; dummy variable $(0=$ low ability to evaluate; 1 = high ability to evaluate)

See Study 1 $-\quad-\quad-\quad-$

Perceived service performance (based on Fornell et al. 1996), 7-point Likert-type scale: "very poor" to "very good"

How do you rate the waitress's competence?

See Study 1 $-\quad-\quad-$

Service satisfaction (based on Voss, Parasuraman, and Grewal 1998),

7-point Likert-type scale: "fully disagree" to "fully agree"

I am very satisfied with the restaurant.

See Study $1 \quad .94$

I am very satisfied with my restaurant choice.

.94

I am very satisfied with the restaurant's quality.

Loyalty to the service provider (based on Homburg and Giering 2001),

7-point Likert-type scale: "fully disagree" to "fully agree"

In the future, I would visit the restaurant again.

See Study $1 \quad .93$

In the future, I would visit the restaurant more frequently.

$.93 \quad .93$

.82

I would recommend the restaurant to my friends.

.94

\section{Study 3}

Service Expectations (based on Fornell et al. 1996),

6-point Likert-type scale: "fully disagree" to "fully agree", collected before the flight

I believe that I will be very satisfied with the flight crew.

board.

I believe that I will be very satisfied with the entertainment program on board.

I believe that I will be very satisfied with the comfort on board.

See Study $1 \quad .75$

I believe that I will be very satisfied with the flight's

timeliness.

Motivation to evaluate (based on Chaiken 1980; Smerecnik et al. 2012),

6-point Likert-type scale: "fully disagree" to "fully agree", collected after the flight

Extent to which a customer

I expended a lot of effort to evaluate the flight experience. exerts effort to assess service performance

Pre-Consumption Loyalty (based on Johnson, Herrmann, and Huber 2006),

6-point Likert-type scale: "fully disagree" to "fully agree", collected before the flight

I will choose this airline in the future.

I will recommend this airline.

See Study 1

Loyalty Program Membership, check box: "yes", "no", collected before the flight

Are you a member of the airline's loyalty program?

Age, open text box, collected after the movie

How old are you?

Gender, check box: "male", "female", collected after the movie

What is your gender?

Notes: $\alpha=$ Cronbach's alpha, $\mathrm{CR}=$ composite reliability, AVE = average variance extracted 


\section{References}

Anderson, Rolph E. (1973), “Consumer Dissatisfaction: The Effect of Disconfirmed Expectancy on Perceived Product Performance,” Journal of Marketing Research, 10 (February), 38-44.

Anderson, Eugene W. and Mary W. Sullivan (1993), “The Antecedents and Consequences of Customer Satisfaction for Firms,” Marketing Science, 12 (2), 125-143.

Bagozzi, Richard P. (1977), "Structural Equation Models in Experimental Research,” Journal of Marketing Research, 14 (May), 209-226.

------ and Youjae Yi (1988), “On the Evaluation of Structural Equation Models,” Journal of the Academy of Marketing Science, 16 (1), 74-94.

Batra, Rajeev and Douglas M. Stayman (1990), “The Role of Mood in Advertising Effectiveness,” Journal of Consumer Research, 17 (2), 203-214.

Baumgartner, Hans, Mita Sujan, and James R. Bettman (1992), “Autobiographical Memories, Affect, and Consumer Information Processing,” Journal of Consumer Psychology, 1 (1), 5382.

Bergkvist, Lars and John R. Rossiter (2007), "The predictive validity of multiple-item versus single-item measures of the same constructs,” Journal of Marketing Research, 44 (2), 175184.

Bitner, Mary Jo, Bernard H. Booms, and Mary Stanfield Tetreault (1990), “The Service Encounter: Diagnosing Favorable and Unfavorable Incidents,” The Journal of Marketing, 1 (Jan), 71-84.

Bizer, George Y., Jon A. Krosnick, Allyson L. Holbrook, S. Christian Wheeler, Derek D. Rucker, and Richard E. Petty (2004), "The Impact of Personality on Cognitive, Behavioral, and Affective Political Processes: The Effects of Need to Evaluate,” Journal of Personality, 72 (5), 995-1028.

Boulding, William, Ajay Kalra, Richard Staelin, and Valarie A. Zeithaml (1993), “A Dynamic Process Model of Service Quality: From Service Expectations to Behavioral Intentions,” Journal of Marketing Research, 30 (February), 7-27.

------, Ajay Kalra, and Richard Staelin (1999), “The Quality Double Whammy,” Marketing Science, 18 (4), 463-484.

Campbell, Margaret C. (2007), ““Says who?!” How the Source of Price Information and Affect Influence Perceived Price (Un) Fairness,” Journal of Marketing Research, 44 (2), 261-271.

Chaiken, Shelly (1980), "Heuristic Versus Systematic Information Processing and the Use of Source Versus Message Cues in Persuasion,” Journal of Personality and Social Psychology, 39 (5), 752-766.

Churchill, Gilbert A. and Carol Suprenant (1982), “An Investigation Into the Determinants of Customer Satisfaction,” Journal of Marketing Research, 19 (November), 491-504.

Cohen, Jacob, Patricia Cohen, Stephen G. West, and Leona S. Aiken (2003), Applied Multiple Regression/Correlation Analysis for the Behavioral Sciences. Mahwah, NJ: Lawrence Erlbaum Associates. 
Davidow, William H. and Bro Uttal (1989), “Service Companies: Focus or Falter,” Harvard Business Review, 67 (July/August), 77-85.

eMarketer (February 2010), "Moms Place Trust in Other Consumers - Influencing One Another,” Survey eMarketer, Expo Communications.

Ford, Gary T., Darlene B. Smith, and John L. Swasy (1990), “Consumer Skepticism of Advertising Claims: Testing Hypotheses From Economics of Information,” Journal of Consumer Research, 16 (4), 433-441.

Forgas, Joseph P. and Jennifer M. George (2001), “Affective Influences on Judgments and Behavior in Organizations: An Information Processing Perspective,” Organizational Behavior and Human Decision Processes, 86 (1), 3-34.

Fornell, Claes and David F. Larcker (1981), “Evaluating Structural Equation Models with Unobservable Variables and Measurement Error,” Journal of Marketing Research, 18 (February), 39-50.

------, Michael D. Johnson, Eugene W. Anderson, Jaesung Cha, and Barbara Everitt Bryant (1996), "The American Customer Satisfaction Index: Nature, Purpose, and Findings," Journal of Marketing, 60 (4), 7-18.

Gelbrich, Katja, Jana Gäthke, and Yany Grégoire (2015), “How Much Compensation Should a Firm Offer for a Flawed Service? An Examination of the Nonlinear Effects of Compensation on Satisfaction,” Journal of Service Research, 18 (1), 107-123.

Golder, Peter N., Debanjan Mitra, and Christine Moorman (2012), "What Is Quality? An Integrative Framework of Processes and States,” Journal of Marketing, 76 (July), 1-23.

Goldstein, Noah, Steve Martin, and Robert Cialdini (2008), Yes! 50 Scientifically Proven Ways to Be Persuasive, New York: Free Press.

Gupta, Kamal and David W. Stewart (1996), “Customer Satisfaction and Customer Behavior: The Differential Role of Brand and Category Service Expectations,” Marketing Letters, 7 (3), 249-263.

Hamer, Lawrence O, Ben Shaw-Ching Liu, and D. Sudharshan (1999), “The Effects of Intraencounter Changes in Expectations on Perceived Service Quality Models,” Journal of Service Research, 1 (3), 275-289.

Hayes, Andrew F. and Kristopher J. Preacher (2014), "Statistical Mediation Analysis With a Multicategorical Independent Variable,” British Journal of Mathematical and Statistical Psychology, 67 (3), 451-470.

Haumann, Till, Pascal Güntürkün, Laura Marie Schons, and Jan Wieseke (2015), “Engaging Customers in Coproduction Processes: How Value-Enhancing and Intensity-Reducing Communication Strategies Mitigate the Negative Effects of Coproduction Intensity,” Journal of Marketing, 79 (6), 17-33.

Hennig-Thurau, Thorsten, André Marchand, and Barbara Hiller (2012), “The Relation Between Reviewer Judgments and Motion Picture Success: Re-Analysis and Extension,” Journal of Cultural Economics, 38 (3), 249-284. 
Herr, Paul M. (1989), “Priming Price: Prior Knowledge and Context Effects,” Journal of Consumer Research, 16 (June), 67-75.

Ho, Teck H. and Yu-Sheng Zheng (2004), "Setting Customer Expectation in Service Delivery: An Integrated Marketing-Operations Perspective,” Management Science, 50 (4), 479-488.

Homburg, Christian and Annette Giering (2001), "Personal Characteristics as Moderators of the Relationship between Customer Satisfaction and Loyalty_an Empirical Analysis,” Psychology \& Marketing, 18 (1), 43-66.

------, Nicole Koschate, and Wayne D. Hoyer (2005), “Do Satisfied Customers Really Pay More? A Study of the Relationship Between Customer Satisfaction and Willingness to Pay,” Journal of Marketing, 69 (2), 84-96.

Hox, Joop J. (2010), Multilevel Analysis: Techniques and Applications (Quantitative Methodology), 2nd ed. London: Taylor and Francis.

Irmak, Caglar, Lauren G. Block, and Gavan J. Fitzsimons (2005), “The Placebo Effect in Marketing: Sometimes You Just Have to Want It to Work,” Journal of Marketing Research, 42 (4), 406-409.

Jaakkola, Elina and Matthew Alexander (2014), “The Role of Customer Engagement Behavior in Value Co-Creation A Service System Perspective,” Journal of Service Research, 17 (3), 247261.

Jain, Shailendra Pratap and Durairaj Maheswaran (2000), “Motivated Reasoning: A Depth-ofProcessing Perspective,” Journal of Consumer Research, 26 (4), 358-371.

James, Oliver (2007), "Evaluating the Service expectations Disconfirmation and Service expectations Anchoring Approaches to Citizen Satisfaction with Local Public Services," Journal of Public Administration Research and Theory, 19 (1), 107-123.

Jarvis, W. Blair G. and Richard E. Petty (1996), “The Need to Evaluate,” Journal of Personality and Social Psychology, 70 (1), 172-194.

Johnson, Michael D., Andreas Herrmann, and Frank Huber (2006), “The Evolution of Loyalty Intentions,” Journal of Marketing, 70 (2), 122-132.

Kopalle, Praveen K and Donald R. Lehmann (2001), “Strategic Management of Service expectations: The Role of Disconfirmation Sensitivity and Perfectionism,” Journal of Marketing Research, 38 (August), 386-394.

(2006), "Setting Quality Expectations When Entering a Market: What Should The Promise Be?,” Marketing Science, 25 (1), 8-24.

Kurtz, David L. and Kenneth E. Clow (1992), “Managing Consumer Expectations of Services,” Journal of Marketing Management, 2 (2), 19-25.

Lee, Leonard, Shane Frederick, and Dan Ariely (2006), “Try It, You'll Like It-The Influence of Expectation, Consumption, and Revelation on Preference for Beer,” Psychological Science, 17 (12), 1054-1058.

Lee, Angela Y. and Aparna A. Labroo (2004), “The Effect of Conceptual and Perceptual Fluency on Brand Evaluation," Journal of Marketing Research, 41 (2), 151-165. 
Lindell, Michael K. and David J. Whitney (2001), “Accounting for common method variance in cross-sectional research designs,” Journal of Applied Psychology, 86 (1), 114-121.

MacInnis, Deborah J. and Bernard J. Jaworski (1989), “Information Processing from Advertisements: Toward an Integrative Framework,” Journal of Marketing, 53 (October), 123.

McCollough, Michael A., Leonard L. Berry, and Manjit S. Yadav (2000), “An Empirical Investigation of Customer Satisfaction After Service Failure and Recovery,” Journal of Service Research, 3 (2), 121-137.

McKinney, Vicki, Kanghyun Yoon, and Fatemeh "Mariam” Zahedi (2002), "The Measurement of Web-Customer Satisfaction: An Expectation and Disconfirmation Approach,” Information Systems Research, 13 (3), 296-315.

Morgan, Neil A. and Lopo Leotte Rego (2006), "The Value of Different Customer Satisfaction and Loyalty Metrics in Predicting Business Performance,” Marketing Science, 25 (5), 426439.

Munoz, Lisa M.P. (2014), "Just Keep Your Promises: Going Above And Beyond Does Not Pay Off,” Sage Publications, May (2014), 1-3.

Muthén, Linda K. and Bengt O. Muthén (2012), Mplus User’s Guide, 7th ed. Los Angeles: Muthén and Muthén.

Nelson, Leif D., Tom Meyvis, and Jeff Galak (2009), “Enhancing the Television-Viewing Experience through Commercial Interruptions,” Journal of Consumer Research, 36 (2), 160172.

Nickerson, Raymond S. (1998), “Confirmation Bias: A Ubiquitous Phenomenon in Many Guises,” Review of General Psychology, 2 (2), 175-220.

Ojasalo, Jukka (2001), “Managing Customer Expectations in Professional Services,” Managing Service Quality: An International Journal, 11(3), 200-212.

Oliver, Richard L. (1980), “A Cognitive Model of Antecedents and Consequences of Satisfaction Decisions,” Journal of Marketing Research, 17 (November), 460-469.

------, P.V. (Sundar) Balakrishnan, and Bruce Barry (1994), “Outcome Satisfaction in Negotiation: A Test of Expectancy Disconfirmation,” Organizational Behavior and Human Decision Processes, 60 (2), 252-275.

and Raymond R. Burke (1999), "Expectation Processes in Satisfaction Formation: A Field Study,” Journal of Service Research, 1 (3), 196-214.

Parasuraman Anantharanthan, Leonard L. Berry, and Valarie A. Zeithaml (1994), "Reassessment of Service expectations as a Comparison Standard in Measuring Service Quality: Implications for Further Research,” Journal of Marketing, 58 (January), 111-124.

Patterson, Paul G., Lester W. Johnson, and Richard A. Spreng (1997), “Modeling the Determinants of Customer Satisfaction for Business-to-Business Professional Services,” Journal of the Academy of Marketing Science, 25 (1), 4-17.

Petty, Richard E. and John T. Cacioppo (1986), "The Elaboration Likelihood Model of Persuasion,” Advances in Experimental Social Psychology, 19, 123-205. 
Podsakoff, Philip M., Scott B. MacKenzie, Jeong-Yeon Lee, and Nathan P. Podsakoff (2003), "Common Method Biases in Behavioral Research: A Critical Review of the Literature and Recommended Remedies,” Journal of Applied Psychology, 88 (5), 879-903.

Poister, Theodore H. and John Clayton Thomas (2011), "The Effect of Service Expectations and Expectancy Confirmation/Disconfirmation on Motorists' Satisfaction with State Highways,” Journal of Public Administration Research and Theory, 21 (4), 601-617.

Sherif, Carolyn W. and Muzafer Sherif, (1967), Attitude, Ego-Involvement, and Change, New York: Wiley.

Shiv, Baba and Alexander Fedorikhin (1999), "Heart and Mind in Conflict: The Interplay of Affect and Cognition in Consumer Decision Making," Journal of Consumer Research, 26 (3), 278-292.

------, Ziv Carmon, and Dan Ariely (2005), "Placebo Effects of Marketing Actions: Consumers May Get What They Pay For,” Journal of Marketing Research, 42 (November), 383-393.

Smerecnik, Chris M. R., Ilse Mesters, Math J. J. M. Candel, Hein De Vries, and Nanne K. De Vries (2012), "Risk Perception and Information Processing: The Development and Validation of a Questionnaire to Assess Self-Reported Information Processing,” Risk Analysis, 32 (1), 54-66.

Spiller, Stephen A., Gavan J. Fitzsimons, John G. Lynch Jr., and Gary H. McClelland (2013), "Spotlights, Floodlights, and the Magic Number Zero: Simple Effects Tests in Moderated Regression,” Journal of Marketing Research, 50 (2), 277-288.

Sujan, Mita (1985), “Consumer Knowledge: Effects on Evaluation Strategies Mediating Consumer Judgments,” Journal of Consumer Research, 12 (June), 16-31.

------, James R. Bettman, and Harish Sujan (1986), "Effects of Consumer Service Expectations on Information Processing in Selling Encounters,” Journal of Marketing Research, 23 (November), 346-353.

Thompson, Edmund R. (2007), "Development and Validation of an Internationally Reliable Short-Form of the Positive and Negative Affect Schedule (PANAS)," Journal of CrossCultural Psychology, 38 (2), 227-242.

Voss, Glenn B., A. Parasuraman, and Dhruv Grewal (1998), “The Roles of Price, Performance, and Service Expectations in Determining Satisfaction in Service Exchanges," Journal of Marketing, 62 (October), 46-61.

Wetzel, Hauke A., Maik Hammerschmidt, and Alex R. Zablah (2014), “Gratitude Versus Entitlement: A Dual Process Model of the Profitability Implications of Customer Prioritization,” Journal of Marketing, 78 (2), 1-19.

Yoon, Carolyn (1997), “Age Differences in Consumers’ Processing Strategies: An Investigation of Moderating Influences,” Journal of Consumer Research, 24 (December), 329-342.

Zeithaml, Valarie A., Leonard L. Berry, and Anantharanthan Parasuraman (1993), “The Nature and Determinants of Customer Service Expectations of Service," Journal of the Academy of Marketing Science, 21 (1), 1-12. 